\title{
KAPITALISASI ISU SYARIAH TERHADAP PERGERAKAN EKONOMI DI PASAR NASIONAL DAN GLOBAL
}

\author{
Wening Purbatin Palupi Soenjoto \\ STITNU Al Hikmah Mojokerto \\ weningblackberry@gmail.com
}

\author{
Septiyan Hudan Fuadi \\ IAIN Ponorogo \\ yhanfuadi@gmail.com
}

\begin{abstract}
This study aims to determine the effect of the capitalization of sharia issues on economic movements in national and global markets and try to answer the problem formulation, namely: first, it can describe capitalization of sharia issues that are starting to develop in sharia economic movements in national and global markets. Second: can describe the process of negotiation (interaction) carried out by producers who use sharia issues in trade. Third: can find the implications of the meaning of the results of research and solutions that can add studies related to sharia issues in the economy in national and global markets so that it can be further investigated by subsequent researchers. The method used in this study is a qualitative method with descriptive analysis. Research subjects are informants who provide research data through interviews, surveys and documentation with triangulation data processing techniques to obtain valid research results. Based on the results of the study, it was concluded that the capitalization of sharia issues could affect national and global market movements
\end{abstract}

Keywords: capitalization, sharia issues, sharia economy, national market, global market

\section{Pendahuluan}

Ekonomi syariah dengan isu-isu syariah menjadi simbol kekuatan perdagangan dunia yang tidak dapat diremehkan oleh para produsen dunia untuk dapat bertahan di pasar nasional dan global. Sistem ekonomi syariah menekankan dimensi ibadah yang teraplikasikan dalam etika dan moral syariah islam. Fenomena kebangkitan ekonomi syariah sangat dirasakan di pasar nasional maupun global, seperti peningkatan kebutuhan-kebutuhan barang maupun jasa bagi para konsumen ,yang sudah tersertifikasi halal untuk makanan,minuman, busana muslim, kosmetik, obat-obatan, permukiman islami hingga pariwisata syariah yang pertumbuhannya begitu cepat. Ini terjadi ditandai dengan tumbuhnya kelompok middle class moeslem di dunia, yang memiliki kemampuan ekonomi 
yang semakin baik dan perdagangan dunia menggunakan prinsi-rrinsip syariah yang membuka peluang pasar lebih luas lagi. Umat muslim menjadi market targeting dimana para produsen non muslimpun mulai menganalisa secara cepat merespon agar dapat mengisi peluang pasar yang makin kompetitif pula untuk mempelajari prinsip syariah dalam mengikuti pola perdagangan dunia saat ini.

Dalam upaya kebangkitan ekonomi syariah di pasar nasional maupun global, tidak terelekan adanya pengkapitalisasian isu-isu syariah untuk mempermudah peluang pasar yang dapat dilakukan oleh para produsen terutama para produsen non muslim yang berorentasikan mendapatkan keuntungan sebesar-besarnya dari peluang pasar sehingga diperlukan berbagai kebijakan pemerataan ekonomi yakni mengenai redistribusi aset dan reforma agrarian.Namun demikian semua program kebijakan tersebut harus benar-benar bersentuhan langsung dengan ekonomi rakyat. Sehingga masa depan ekonomi syariah yang gemilang akan menjadi kenyataan. Untuk mewujudkan kebangkitan ekonomi syariah di pasar global harus dilakukan secara berjamaah. Jika ditopang dengan kekuatan ekonomi yang kuat dan besar, kebangkitan ekonomi syariah bisa menjadi solusi bagi perekonomian dunia. Secara realita pada saat ini, gerakan ekonomi umat secara berjamaah dan pemerintah harus mendukung karena negara-negara mayoritas muslim terbesar menjadi target pasar para produsen dunia.

Adapun tujuan penelitian ini pada intinya berusaha menjawab rumusan masalah yaitu: pertama, dapat mendiskripsikan pengkapitalisasian isu syariah yang mulai berkembang dalam pergerakan ekonomi di pasar global. Kedua: dapat menggambarkan proses negosiasi (interaksi) yang dilakukan para produsen yang menggunakan isu syariah dalam perdagangan. Ketiga: dapat menemukan implikasi makna dari hasil penelitian dan solusi yang dapat menmabah kajian terkait isu syariah dalam perekonomian di pasar nasional dan global agar dapat lebih lanjut diteliti oleh para peneliti selanjutnya.

\section{Metode Penelitian}

Penelitian ini menggunakan penelitian kualitatif yang merupakan penelitian yang menghasilkan dan mengolah data bersifat diskriptif dengan melakukan 
search library. Untuk mencapai validasi data yang lebih objektif dan akurat dalam penyesuaian hasil penelitian. Penelitian ini termasuk jenis penelitian lapangan yang bersifat deskriptif kualitatif. Penelitian ini model penyajianya dilakukan dengan cara menggambarkan obyek yang diteliti secara apa adanya dengan penyataanpernyataan yang bersifat kualitatif. Dalam penelitian kualitatif memerlukan pada penekanan pentingnya kedekatan dengan orang-orang dan situasi penelitian agar peneliti memperoleh pemahaman jelas tentang realitas dan kondisi kehidupan nyata dan penelitian ini meneliti dan mewawancarai para produsen muslim dan non muslim untuk mengetahui pengaruh isu-isu syariah seperti penerapan sertifikasi halal baik untuk barang maupun jasa terhadap hasil penjualan ${ }^{1}$. Berdasarkan Teknik Triangulasi (Technique Triangulation) agar proses penelitian dapat menghasilkan hasil data yang valid selain melakukan dokumentasi dan survey.

Observasi lapangan berupa kegiatan wawancara, para produsen yang sudah menerapkan prinsip ekonomi syariah maupun yang belum, para produsen muslim dan non muslim serta dokumen pendukung berupa catatan administrasi yang berguna untuk menganalisis data sebagai berikut:

a. Pengolahan Data

Penulis menggunakan Teknik Triangulasi (Technique Triangulation) diartikan sebagai teknik pengumpulan data yang bersifat menggabungkan dari berbagai teknik pengumpulan data dan sumber data yang telah ada sebagai perspektif untuk menafsirkan sebuat set data. Peneliti menggunakan observasi yaitu dengan langsung melakukan survey lapangan ke pasar dan toko-toko, wawancara dilakukan dengan mewawancarai wirausaha muslim maupun non muslim, dan dokumentasi untuk sumber data yang sama secara serempak selain melakukan search library terhadap Al Quran,hadist,fatwa MUI dan buku-buku yang menambah kajian tulisan. Tujuan dari triangulasi bukan untuk mencari kebenaran tentang beberapa data, tetapi lebih pada peningkatan pemahaman peneliti terhadap apa yang telah ditemukan dan lebih baik saat memahami data. menghasilkan kesimpulan analisis sama, maka validitas penelitian.

\footnotetext{
${ }^{1}$ Sugiyono. Metode Kualitatif. (Bandung: Alfabeta, 2017)
} 
b. Display Data

Sejumlah tinjauan maupun kajian tentang prinsi-prinsip syariah, ekonomi syariah yang sesuai untuk memudahkan secara ringkas dan cepat menunjukkan cakupan data yang telah di kumpulkan oleh peneliti apabila dianggap masih belum lengkap.

c. Penarikan Kesimpulan

Kegiatan analisis data kualitatif pada penulisan atau penuturan tentang apa yang dapat dimengerti dan berkaitan dengan segala sesuatu masalah yang diteliti dan menelaah kesimpulan yang komprehensif berdasarkan fokus masalah cacatan, pengorganisasian yang bersifat interpretasi.

Dalam tulisan ini masih merupakan penelitian untuk itu diperlukan waktu penelitian yang bekelanjutan. Jika diadakan penelitian tidak hanya dilakukan search library dengan menguak beberapa ayat di Al Qur'an,hadist dan kajian fiqh lainnya tetapi juga bahwa antara penerapan isu syariah terhadap pergerakan ekonomi di pasar nasional dan global tidak hanya diteliti berdasarkan konsepkonsep ekonomi Islam namun juga harus ada perbandingan secara teori-teori ekonomi konvensional yang direlevansikan kegiatan dan faktor-faktor produksi pendukung terjadinya interaksi dan komunikasi produsen-konsumen yang saling mempengaruhi terciptanya transaksi ekonomi di pasar nasional dan global walaupun yang terlibat didalamnya adalah semua produsen muslim maupun non muslim.

\section{HASIL DAN PEMBAHASAN}

Pemahaman isu syariah yang dicerna masyarakat awam dan para produsen terutama produsen non muslim lebih merujuk pada sederhana yang membutuhkan sosislaisai dan edukasi lebih mendalam bukan hanya berdasarkan pada peluang pasar yang menimbulkan gerakan kompetitif dari para produsen untuk mendapakan keuntungan sebesar-besarnya bahkan negara-negara lain yang mayoritas non muslim sudah mulai menerapkan isu syariah seperti penerapan sertifikasi halal di bidang perindustrian,perdagangan,pariwisata serta perbankan sehingga bisa dicermati bahwa penerapan isu syariah menjadi arus baru yang berupa selling point untuk mendapatkan targetting market yang lebih luas di 
pasar global dan tanpa disadari isu syariah pun dikapitaliasasi demi mengeruk keuntungan yang lebih besar dan ini merupakan tujuan perusahaan yang dimiliki produsen muslim maupun non muslim.

Era globalisasi dan kecanggihan teknologi menuntut semua negara yang melakukan perdagangan internasional. Persaingan semua aspek dalam bidang industri memaksa semua pelaku bisnis "membaca"peluang usaha yang dapat diraih. Dibuka pintu-pintu peluang usaha seluasnya mendapatkan keuntungan sebesar-besarnya. Penerapan syariah dijadikan marketing issue yang mampu menarik perhatian konsumen terutama umat muslim. Manusia adalah makhluk sosial dan organisasional dalam hal ini terjadi dalam siklus bisnis atau dunia usaha yang menuntut manusia-manusia produsen bersaing ketat untuk mendapatkan konsumen. Karena itu produsen tidak dapat hidup sendiri tanpa berkoordinasi dengan manusia lainnya seperti mata rantai usaha dan konsumen sebgai sasaran pasar. Koordinasi perlu bahkan sangat dibutuhkan karena setiap produsen atau pemilik usaha butuh koordinasi untuk mempererat solidaritas dengan pihak lain. Bahkan koordinasi diperlukan dalam setiap organisasi kecil dan besar, baik organisasi yang sederhana maupun organisasi yang kompleks. Dalam organisasi selalu ada hal-hal yang saling berkaitan dan perlu dikoordinasikan hingga terbentuk jaringan kerja yang berkelanjutan.

Setiap produsen harus memiliki banyak cara yang sistematis mengisi peluang pasar nasional dan global dalam memandang sebuah resiko dan menentukan dengan tepat penanganan resiko tersebut terutama dalam membaca peluang terbukanya penerapan isu syariah. Ini merupakan sebuah sarana untuk mengidentifikasi sumber dari resiko dan ketidakpastian serta memperkirakan dampak yang ditimbulkan dan mengembangkan respon yang harus dilakukan untuk menanggapi resiko agar tidak hanya mengikuti arus tren dalam penerapan isu-isu syaiah. Bahwa pemahaman isu-isu syariah para produsen tidak hanya sekedar mengenal seperti penerapan setiikasi halal pada barang maupun jasa bahwa logo halal bukan sekedar logo yang mengandung selling point namun lebih pada pemahaman para konsumen memilih produk barang atau jasa yang tersertifikasi halal sehingga tercipta mata rantai bisnis secara simbiosis mutualisme antara produsen dan konsumen. 
Penerapan isu syariah dalam pegerakan ekonomi di pasar nasional dan global ini berguna untuk mengambil keputusan penerapan isu syariah dalam menangani masalah-masalah rumit yang akan timbul jika hanya mengambil peluang pasar untuk mendapatkan keuntungan yang sebesar-besarnya dengan menganalisa keadaan perusahaan-perusahaan seperti analisa :

1. Memudahkan estimasi biaya jika memang sudah meraup keuntungan dalam penetrasi pasar dengan diimbangi manejemen yang bermutu.

2. Memberikan pendapat dan intuisi dalam pembuatan keputusan yang dihasilkan dalam cara yang benar terutama pemahaman pada para konsumen pemakai produk barang atau jasa. Memungkinkan bagi para pembuat keputusan dalam hal ini adalah para produsen untuk menghadapi resiko dan ketidakpastian dalam keadaan yang nyata karena semakin banyak produsen yang akan segera membaca peluang pasar yang menguntungkan setelah penerapan isu-isu syariah seperti logo halal maupun penggunaan kata syariah terhadap beberapa produk selain makanan minuman sehingga persaingan semakin besar pula.

3. Memungkinkan bagi para pembuat keputusan untuk memutuskan berapa banyak informasi yang dibutuhkan terkait proses dalam pemakian isu-isu syariah maupun sertifikasi halal dan setelah mendapat legalitas menggunakan kata syariah ataupun sertifikasi halal dalam menyelesaikan masalah yang akan timbul di kemudian hari karena akan ada penilian secara berkala dan berkelanjutan dalam kebijakan pemerintah maupun para produsen tentang penerapan isu syariah.

4. Meningkatkan pendekatan sistematis dan logika untuk membuat keputusan dalam penerapan isu syariah yang mampu mendorong pergerakan ekonomi di pasar nasional dan global. Menyediakan pedoman untuk membantu perumusan masalah.

5. Memungkinkan analisa yang cermat dari pilihan-pilihan alternative dalam hal ini penerapan isu syariah tetap merupakan kebijakan yang bisa dilakukan tidak hanya pada barang-barang berupa makanan, minuman,kosmetik dan obat-obatan namun juga pada sektor jasa. 
Kapitalisme merupakan sebuah sistem organisasi ekonomi yang dicirikan oleh hak milik privat atas alat-alat produksi dan distribusi yang pemanfaatannya untuk mencapai laba dalam kondisi yang sangat kompetitif (Milton $\mathrm{H}$. Spencer:1990). Penerapan isu-isu syariah dalam mendorong pergerakan ekonomi menjadi poin terpenting yang dipahami secara eksplisit oleh para produsen non muslim hanya menilai bahwa dengan penerapan isu -isu syariah maka keuntungan smaksimal dapat diraih dan ceruk pasar sasaran lebih mudah dikendalikan.Selajutnya pengertian sistem ekonomi kapitalis adalah suatu sistem yang memberikan kebebasan yang cukup besar bagi pelaku-pelaku ekonomi untuk melakukan kegiatan yang terbaik bagi kepentingan individual atas sumberdaya-sumberdaya ekonomi atau faktor-faktor produksi. Pada sistem ekonomi ini terdapat keleluasaan bagi perorangan untuk memiliki sumberdaya, seperti kompetisi antar individu dalam memenuhi kebutuhan hidup, persaingan antar badan usaha dalam mencari keuntungan.

Prinsip "keadilan" yang dianut oleh sistem ekonomi kapitalis adalah setiap orang menerima imbalan berdasarkan prestasi kerjanya. Dalam hal ini campur tangan pemerintah sangat minim, sebab pemerintah berkedudukan sebagai "pengamat" dan "pelindung" dalam perekonomian². Dari beberapa pengertian tersebut diatas tidak ada yang luput dari yang diajarkan oleh Adam Smith melalui bukunya yang terbit pada tahun 1776 dengan judul An Inquiry the nature and Cause of the wealth of nation yang menghendaki setiap orang diberi kebebasan untuk bekerja dan berusaha dalam persaingan sempurna yang meniadakan sama sekali intervensi pemerintah.

Dalam penerapan isu syariah maka pasar dan pemasaran merupakan dua sisi yang tidak dapat dipisahkan satu sama lainya. Para produsen di semua sektor perindustrian dan perdagangan akan membentuk pasar dan pemasaran yang memiliki tingkat ketergantungan yang tinggi dan saling memengaruhi satu sama lainya. Dengan kata lain, setiap ada kegiatan pasar selalu diikuti oleh pemasaran dan setiap kegiatan pemasaran adalah untuk mencari atau menciptakan pasar sehingga dapat mencapai penetrasi pasar bahwa segmentasi terbentuk secara

\footnotetext{
${ }^{2}$ Subandi. Ekonomi Kapitalis. (Jogjakarta : Liberty Yogyakarta, 2005)
} 
alami karena adanya faktor saling ketergantungan anata produsen dan konsumen. Produsen menganalisa peluang dimana para konsumen akan merasa aman jika terdapat logo halal pada barang atau jasa yang sudah tersertifikasi halal.

Pengertian pembentukan segmentasi pasar secara sederhana dapat diartikan sebagai tempat bertemunya penjual dan pembeli untuk melakukan transaksi. dalam keadaan pasar nasional dan global yang menuntut strategi yang tepat untuk bertahan maka pra produsen harus jeli membaca celah atau ceruk pasar. Pengertian ini mengandung arti membentuk pasar terkadang tidak membutuhkan tempat atau lokasi tertentu dimana terciptanya komunitas konsumen yang merespon pasar namun lebih pada memungkinkan kemudahan pembeli dan penjual bertemu untuk melakukan transaksi jual beli produk baik barang maupun jasa. Dalam hal ini penerapan isu syariah menjadi selling point yang jitu untuk melakukan targetting market.

Pengertian lain yang lebih luas tentang pasar yang terbentuk adalah himpunan pembeli nyata dan pembeli potensial atas suatu produk yaitu barang dan jasa. Dari pengertian ini mengandung arti bahwa produsen yang peka menganalisa pasar sehingga konsumen lebih percaya mengkonsumsi produk dengan adanya logo halal merupakan kumpulan atau himpunan para produsen dan para pembeli, baik pembeli nyata maupun pemebeli potensial atas suatu produk barang dan jasa tertentu.

Pasar yang tercipta karena dampak penerapan logo halal juga dapat diartikan pula sebagai suatu mekanisme yang mempertemukan antara pembeli dan penjual atau tempat pertemuan antara kekuatan permintaan dan penawaran. Yang dimaksud permintaan sendiri adalah jumlah barang dan jasa yang diminta konsumen pada berbagai tingkat harga pda suatu waktu tertentu. Sedangkan penawaran adalah jumlah barang atau jasa yang ditawarkan produsen pada berbagai tingkat harga pada suatu waktu tertentu. Dalam proses permintaan dan penawaran inilah muncul kapitalisasi isu syariah seperti penerapan logo halal di pasar nasional dan global karena konsumen mulai sadar akan konsumsi barang dan jasa yang sudah tersertifikasi halal secara harga jelas lebih mahal namun secara keamanan mengkonsumsi menimbulkan kepercayaan konsumen. 
Memasuki pasar global membutuhkan pengembangan usaha yang lebih proaktif namun tetap efektif dan efesien. Pasar global menuntut para produsen cermat menganalisa dan mengendalikan pasar karena membuat para konsumen cerdas dengan memerlukan edukasi dalam komunikasi,interaksi dan terjadinya transaksi membutuhkan proses berkelanjutan terutama penerapan logo halal dalam kemasan barang maupun dalam bidang jasa .

Jika kita menganalisa tren penerapan isu-isu syariah maka semakin mendoronng sistem ekonomi kapitalis dalam pengertiannya para produsen boleh melakukan kegiatan ekonominya sesuai dengan kemampuannya sendiri tanpa campur tangan pemerintah, sistem ekonomi yang didasarkan pada pemilikan pribadi atas sarana produksi dan distribusi untuk kepentingan pencarian laba pribadi ke arah pemupukan melalui persaingan bebas. Dengan memiliki sertifikasi halal maka produsen makin leluasa mendapatkan peluang pasar yang lebih luas. Dalam perekonomian kapitalis setiap warga dapat mengatur nasibnya sendiri sesuai dengan kemampuannya. Semua produsen bebas bersaing dalam bisnis untuk memperoleh laba sebesar-besarnya bahkan bebas malakukan kompetisi untuk memenangkan persaingan bebas dengan berbagai cara. Para produsen akan memunculkan asumsi dengan penerapan sertifikasi halal merupakan pemenuhan kepentingan pribadi oleh semua individu (dalam hal ini para produsen) juga akan secara otomatis memenuhi kepentingan sosial bersama. Namun, secara pesan terselubung bahwa produsen melakukan penerapan isu-isu syariah lebih pada keuntungan yang lebih besar didapat setelah memakai isu-isu syariah.

Dalam Islam sudah sangat dipetakan secara jelas tentang pemanfaatan faktor-faktor produksi yang tertera di surat An-Nisaa' ayat 29

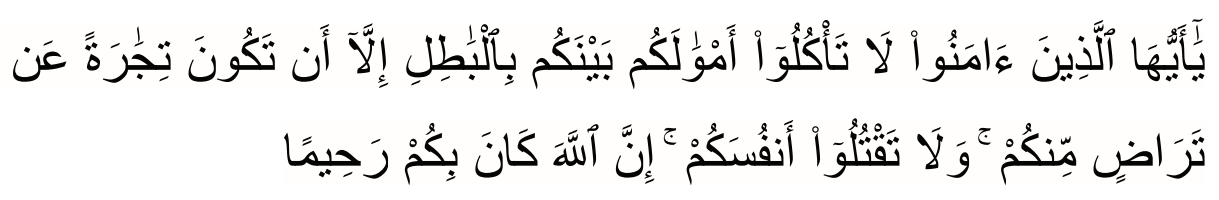

Artinya: "Hai orang-orang yang beriman, janganlah kamu saling memakan harta sesamamu dengan jalan yang batil, kecuali dengan jalan perniagaan yang berlaku dengan suka sama-suka di antara kamu. dan janganlah kamu membunuh dirimu; Sesungguhnya Allah adalah Maha Penyayang kepadamu."

Islam mendorong manusia untuk bekerja dan berjuang untuk mendapatkan materi atau harta dengan berbagai cara, asalkan mengikuti aturan yang telah 
ditetapkan. Hal ini dijamin oleh Allah SWT bahwa Allah telah menempatkan rizki setiap makluk yang diciptakannya. Kepemilikan kekayaan tidak boleh hanya dimiliki oleh segelintir orang-orang kaya, dan harus berperan sebagai kapital produktif yang akan meningkatkan kesejahteraan masyarakat. Islam menjamin kepemilikan masyarakat dan penggunaannya dialokasikan untuk kepentingan orang banyak. Pernyataan tersebut menjelaskan bagaimana ekonomi syariah harus diterapkan dalam transaksi perdagangan namun pada realita pasar, tidak semua produsen muslim melakukannya bahkan para produsen non muslim yang menganut paham kapitalisme menjadi kompetitor bagi para produsen muslim.

Dalam ekonomi Islam, Aqidah sebagai substansi (inti) yang menggerakkan dan mengarahkan kegiatan ekonomi. Syari'ah sebagai batasan untuk memformulasi keputusan ekonomi. Akhlak berfungsi sebagai parameter dalam proses optimalisasi kegiatan ekonomi. Maka Islam tidak saja memberi kebebasan tetapi terhadang dalam ekonomi malah ia juga memberikan perlindungan terhadap apa yang diperolehi. Nilai - nilai akhlak dan sifat - sifat menjadi asas pengisian prinsip berkenaan. Cara mendapatkan harta haruslah dengan jalan yang halal (bukan dengan melakukan amalan riba, penipuan, perampokan, ekspolitasi dan cara - cara yang bertentangan dengan syariat Islam. Majelis Ulama Indonesia diharapkan mampu menjembatani anatara produsen dan konsumen. Membutuhkan proses panjang agar mampu menjadi sumber komunikasi yang optimal dalam penerapan halal segala bidang industri di Indonesia.Dalam penerapan sertifikasi halal yang sekarang menjadi tren di dunia usaha dapat dianalisa dengan menggunakan teori pemasaran dan segmentasi pasar untu bisa menilai pasar lebih peka. Para produsen menjadikan logo halal tidak sekedar objek meraup keuntungan yang lebih besar melainkan memahami konsumen dalam konsep bernafaskan keagamaan walaupun produsen tersebut adalah produsen non muslim.

\section{KESIMPULAN}

Kata halal dan syariah menjadi selling point penting dimana posisi produk diterima konsumen adalah bagaimana suatu produk yang didefinisikan oleh konsumen atas dasar atribut-atributnya dan penerapan isu-isu syariah seperti 
sertifikasi halal maupun label syariah pada produk barang atau jasa menjadi tujuan penetapan posisi pasar (market positioning) untuk membangun dan mengkomunikasikan keunggulan bersaing produk yang dihasilkan kedalam benak konsumen. Para produsen baik muslim maupun non muslim harus peka membaca dan meraih peluang di pasar nasional dan terutama di pasar global.Knowing your customer belakangan ini menjadi strategi pemasaran untuk dapat mendapat perhatian para konsumen dan juga sangat penting bagi setiap pelaku usaha. Tujuannya agar para produsen merespon apa yang mereka butuhkan dan inginkan maka mulai maraknya penerapan logo halal dan syariah dijadikan yang strategy movement yang jitu untuk menarik konsumen agar melakukan transaksi. Karena kebutuhan dan keinginan para konsumen setiap saat berubah, maka kegiatan untuk mengetahui dan memahami konsumen juga harus terus dilakukan. Konsumen dan perilaku konsumen yaitu merupakan hubungan yang kuat tentang seluruh usaha guna menggerakkan produk barang dan atau produk jasa dari dari produsen ke konsumen atau pengguna akhir. Fatwa-fatwa yang dikeluarkan Majelis Ulama Indonesia terkait dalam penerapan isu-isu syaria seperti seperti sertifikasi halal sering kita temui di kemasan makanan minuman dan menjadi acuan masyarakat merasa aman mengkonsumsinya.

Selama ini isu-isu syariah dipahami masyarakat luas lebih pada sertifikasi halal untuk makanan minuman yang tidak mengandung daging atau lemak babi,perbankan syariah yang bebas riba,pariwisata syariah yang dianggap hanya khusus turis muslim,tanpa pemahaman yang lebih detail dan mampu dipercaya masyakat. Dalam memenuhi kebutuhan dan keinginannya konsumen memiliki sejumlah perilaku, yang dalam literatur sering disebut dengan perilaku konsumen (customer behavior). Para pelaku usaha perlu mempelajari dan memahami perilaku konsumen. Terutama memahami berbagai faktor yang akan mempengaruhi konsumen dalam mengambil keputusan untuk membeli atau tidak membeli.

Selama ini para produsen difokuskan pada bagaimana individu-individu membuat keputusan untuk menghabiskan ketersediaan sumber daya yang mereka miliki, seperti waktu, uang dan usaha, untuk mengonsumsi barang kebutuhan 
terkait, termasuk didalamnya jawaban dari pertanyaan-pertanyaan tentang apa yang mereka beli, mengapa mereka membeli itu, kapan mereka membeli itu, seberapa sering mereka membeli itu dan lain-lain. Namun setelah Majelis Ulama Indonesia menerapkan sertifikasi halal pada produk barang maupun jasa menjadi pola baru dalam dunia usaha yaitu tejadinyanya kapitalisasi halal di pasar global. Banyak produk makanan minuman berlogo halal yang diproduksi perusahaan multi nasional maupun produsen luar negeri yang bukan perusahaaan yang pemiliknya non muslim dengan cara menampilkan logo halal agar bisa diterima masyarakat kaum muslim. Kata halal dan syariah menjadi harga mati yang harus ada dalam kemasan barang dan bidang jasa maka jika tidak tercantum masyarakat muslim akan menilai haram .Walaupun tidak semua makanan minuman berlogo halal tetap dipercaya masyakat itu halal untuk dikonsumsi atau bahkan banyak masyakat yang tidak mempermasalahkannya. Terutama di Indonesia, kata halal dan syariah selalu menjadi isu penting yang memiliki kekuatan menarik konsumen hingga konsumen mau membeli dan mengkonsumsinya.

Terbentuknya kapitalisasi dalam proses penerapan isu-isu syariah untuk mendorong pergerakan ekonomi di pasar nasional dan global menjadi peluang pasar yang sangat menggiurkan di pasar global. Kemudahan perdagangan membuka segmentasi pasar tanpa batas. Kekuatan Dewan Halal Dunia,Majelis Ulama Indonesia,peran pemerintah dan masyarakat terurtama masyarakat muslim dalam penguatan pola pikir masyarakat maupun para produsen di pasar global tentang isu-isu syariah perlunya sosialisasi berkelanjutan agar isu-isu syariah tidak dipahami sekedar pencetakan logo halal dalam kemasan makanan minuman dan kata syariah pada bidang jasa seperti asuransi,pariwisata hingga perbankan namun menjadi pola kesetiaan pelanggan (Loyality Customers) dan harus mampu menjadi keunggulan kompetitif di pasar nasional dan global yang membentuk masyarakat lebih cerdas dan melek isu-isu syariah bukan dibodohi yang menjadikan isu-isu syariah sebuah pola kapitalisasi sebagai alasan mendorong pergerakan ekonomi syariah di pasar nasional dan global. Dibutuhkan adanya penelitian lebih lanjut dengan rujukan-rujukan secara kajian keislaman maupun konvensional karena proses multidimensi yang terus 
berkembang dan melibatkan perubahan-perubahan mendasar dalam semua struktur pergerakan ekonomi di pasar nasional maupun global.

\section{Daftar Pustaka}

Aziz, Abdul., dan Ulfa, Mariyah. Kapita Selekta Ekonomi Islam. Bandung: Alfabeta, 2010

Abdullah, Boedi. Peradaban Pemikiran Ekonomi Islam. Bandung: Pustaka Setia, 2010.

Dillard, Dudley. Sales and Marketing. London: 1987.

Priyatno, Duwi. Laporan Keuangan. Yogyakarta: Best Publisher, 2009.

Fahmi, Irham, Manajemen Kinerja. Bandung: Alfabeta, 2010.

Hariandja, Tua Marihot Efendi, Manajemen Sumber Daya Manusia. Jakarta: PT. Gramedia Widiasarana Indonesia, 2002.

Kasmir, Jakfar. Studi Kelayakan Bisnis Edisi Revisi. Jakarta: Prenada Mediagroup, 2016.

Munawir, S, Analisa Laporan Keuangan. Jogjakarta: Liberty Yogyakarta, 2012.

Milton H. Spencer; Economic, London: Mac Millan, 1990.

Nitisusastro, Mulyadi. Kewirausahaan Dan Manajemen Usaha Kecil. Bandung: Alfabeta, 2010.

Rivai, Veithzal. Islamic Marketing Membangun Membangun dan Mengembangkan Bisnis dengan Praktik Marketing Rasulullah SAW. Jakarta: Gramedia Pustaka Setia,2012.

Sudantoko, Padji Anoraga dan Djoko, Koperasi, Kewirausahaan dan Usaha Kecil, Rineka Cipta, 2002

Subandi. Ekonomi Kapitalis, Jogjakarta: Liberty Yogyakarta, 2005.

Sumarni, Murti. Manajemen Pemasaran Bank. Yogyakarta: Liberty, 2011.

Widyarini. Manajemen Bisnis dengan Pendekatan Islam. Yogyakarta: Ekonisia, 2012.

Yusanto, Muhammad Islmail. Widjajakusuma, Muhammad Karebet. Menggagas Bisnis Islami. Depok: Gema Insani,2008.

Soenjoto, Wening Purbatin Palupi. "Menata Ulang Kekuatan Ekonomi Islam Di Persaingan Internasional”. Jurnal At Tahdzib. 2013

Soenjoto, Wening Purbatin Palupi. "Mengkaji Krisis Ekonomi Global Menurut Perspektif Islam". Jurnal Taffaquh IAIBAFA. 2017.

Soenjoto, Wening Purbatin Palupi. "Tantangan Bank Syariah Di Era Globalisasi”. Jurnal El Barca IAIN Ponorogo. 2018. 